\title{
Methods of Forming Lingua-Cultural Competence in Postgraduate Education System
}

\author{
A.P.Mynbayeva ${ }^{1}$ \\ R.A.Shahanova ${ }^{2}$ \\ B.Zhanaikhan ${ }^{3}$ \\ 1 PhD Doctoral candidate, Kazakh National Pedagogical University named after Abai \\ 2 Doctor of Pedagogical science, professor, Kazakh National Pedagogical University named after Abai \\ ${ }^{3} \mathrm{PhD}$ Doctoral candidate, Suleyman Demirel University
}

\section{Doi:10.5901/mjss.2015.v6n4s1p172}

\section{Abstract}

We should pay special attention to the fact that the word "competence" is a derivative from the word "competency". In the scientific glossary of terms of the Kazakh language it's written: "competence, in general, is an ability to complete the task or to do something." From Latin, "competence" means skilled, capable, experienced. And we are considering the "lingua-cultural competence", individual's ability to gain knowledge and skills, and develop cultural speaking through text and through logical thinking by operating with the signals that came to the brain cortex on time. Text became the subject of research in linguistics in late XX century. Study the text's distinctive nature is important not only for linguistics, but also for the process of teaching language and for pedagogical basis. However our aim is not creating a text but to distinguish individual's peculiarities through it. Methodological direction, on the one hand, is to show text's function in teaching small units of language, and on the other hand, teach text's distinctive nature in connection. Language given to man common, we do not choose your language and get the language out there, where they were born, where we grow and discover the world. Language covers the picture of development of the world, he absorbs knowledge about the world, which accumulates as much as living language and speaks it people. Language is passed from generation to generation, and with it - the spiritual and the practical experience of the people. It is no accident that the great Wilhelm von Humboldt wrote: "It is clear what a single force is negligible before the mighty power of language ...".

Keywords: competence, text, language, culture, master's degree.

\section{Introduction}

It's been quite a long since we connected our country's independence and the independence of our language and starts to improve the importance of the native language. Also documents with strategic importance as: "Conclusion of language policy in the RK", "Law about language in the RK" is the step forward in achieving this aim. Language is a means of communication. It's a mirror that reflects people's worldview, cultural level, intelligence and spiritual wealth. People always paid special attention to language culture's actuality. Kazakh people have always attached great importance to speaking skill by saying "Language is the beginning of an art." And nowadays actuality of language culture has increased.

In the Kazakhstan President's "Program of language usage and development" it's said: "Language development is one of the most urgent directions in the RK's policy," and "The number and quality of teaching state language should be paid attention."

According to the law of post-higher education, in this continuous education person's lingua-cultural, professional, informational and managing competence will continue to be improved. Because, nowadays bachelor's degree is considered unfinished high education and thus, competences will be formed to train competitive professionals. The process of post-higher education is carried out in all developed and developing countries. In any case, we'll be following the direction of anthropo-actuality.

In connection with training specialists, according to common educational standards, among the terms knowledge, skills, professionalism, the word "competence" is also can be found. It has the following definition: "This term often used in eastern educational system, theoretical-scientific and applied researches. The definition of this term is widely used to evaluate results of learning in academic norms. Competence is a correct evaluation of graduates in connection with their readiness to meet high practical and professional requirement in labor market." (Baydenko, 2004). Cultural competence includes the following: a) understanding individual's own cultural worldview b) relations between cultural differences c) 
individual's cultural notion.

Over the time, requirements for language culture have increased. There're still discussions about the language culture. And just like language and people have been connected, cultural speaking and society are connected too.

"Culture" means bearing in mind the laws that are acceptable for certain norms. The culture of language an ethics of keeping those norms. Linguistic culture is the correctness of language, its clearness. "Culture of speech" is a concept with multiple meanings. According to L.I.Skvortsov, "Culture of speech is knowing the rules of oral and written literary language, rules of pronunciation, accent, grammar, usage, etc.), as well as the ability to use expressive language means in different contexts relations in accordance with the objectives and content of speech". To develop culture of speech decisive actions from nation and people are important.

Relation between language and culture is often described with metaphors: language is the basis of culture, the construction material (V.N.Toporov, D.B.Gudkov), culture means, strength of spirit ( $F$. Von Humboldt), cultural phenomenon, culture's appearance, its look (V.A.Maslova), culture's significance, its guarding shelter, factor of development (C.Levi-Strauss), manual to culture (E.Sapir), path that leads to culture (A.I.Kuprin).

N.Ualiyev wrote that we should consider norms of lingua-cultural layers as well as conveying speaker's thoughts to listener as something close and familiar (Ualiev, 1984).

According to V.A.Sukhomlinsky, speech culture of the individual is the mirror that reflects his spiritual culture and the main tool in exchanging his ideas and feelings.

Doctor of Pedagogics, professor A.Zhapbarov gives the following requirements to high speech culture:

- $\quad$ systematization and clarity of words;

- correct construction of the words according to orthoepic, grammatical and lexical norms;

- words' elegance, figurativeness, emotionality when needed;

- $\quad$ words' correspondence to speaker's or listener's state, needs of the environment (Zhapbarov, 1991).

\section{Methods}

There was an experiment on creating lingua-cultural competence of masters' degree students in post-higher education system. It involved 60 M.A. students divided into 3 stages. By method used at their own stage, M.A. students have demonstrated their knowledge on subjects that they had on 1st semester. To achieve various aims in working with text, we used following methods, such as: I.Lerner's method, informational-receptive, reproductive, problematic reading, everistic, and method of research (Lerner, 1981).

The concept of cultural and linguistic competence necessary to include the willingness of the person to identify at national and social basis, a variety of behavioral practices, and their prediction understanding of the motives. Cultural and linguistic competence is based on idea of national consciousness communicants. native speaker It recognizes that this language is native for him. In it, he thinks, with based on it, he considers himself to varying lingvokulturnoj group differentiates individuals on the grounds of "your/someone else."

\section{Main Part}

The notion of competence, which is the part of conditions for modernization and its conclusion, suitable for international standards, is often used in pedagogical literature. And we should be able to distinguish from each other the concepts of "competency" and "competence" that are often used as synonyms.

Competency is individual's set of qualities (knowledge, skills). i.e. in relation to established environment.

Competence is to manage people in relation to the individual's attitude and towards their action. "Basics of pedagogical skills" L.V.Zanina (Zanina, 2008) and N.P.Menshikova.

Competence is a conclusion that focuses from content to form, not from form to content. Therefore, competent person is not only aware of many things, but also skilled in finding his own place in life, recognizing certain events and solving various problems.

In post-higher education we can form lingua-cultural competence with text. Through theoretical aspects of text analysis we can train future specialists for each category and improve their competent skills, and it will be an issue of its own.

Speech culture is a platform for the success of uninterrupted education and formation the individual as person and specialist. In addition, it considers recognized actions of a person as connected with the country's development and provides main functional knowledge with highest level of competence.

Knowledge is a component of culture, as well as its carrier, its main condition to live, to be saved and widened. In 
pedagogic human is the most significant value by cultural spiritual importance. In addition, individual is an active subject of cognition, communication and creativity.

Nowadays, poor knowledge of native language lead Kazakh people to ignorance, indifference and illiteracy. Low level of speech culture as an indicator of illiteracy affected the economy and democracy. In this context, specialists' effort to create and develop speech culture is used in wide range in the country. This is why in post-higher educational system lingua-cultural competence of philologists is a huge problem. When preparing philologists it's important to control correct usage of words, formation of individual person, his self-development with the course of time and forming lingua-cultural competence. Thus, to make a progress in this issue, we take a text, particularly its linguistic, pedagogical, and psychological basis and educational significance.

In our research, we know that text is based on the connection between meaningful and individualistic linguistic signs. A.Arkin wrote: "Text is profitable mean in directing the knowledge to individual" (Arkin, 2001) thus, specifying our opinion. F.Orazbayeva says: "In linguistic relations words, phraseological units, sentences and text have their own place and significance. Text is a whole system distinguished by contextual integrity in individual's communicaition" (Orazbayeva, 2000). According to E.D.Suleymenova, text by its context is too moveable unit. The significance of this ability is connected to the determination by motivation, and the nature of than motivation is distinctive (Syleymenova, 1989). Nowadays formation of lingua-cultural competence in pupils and students with the help of text is often discussed, however this issue is still not addressed in post-higher education. For example, there are works like M.Mukhamedkalyeva's methodology of teaching Kazakh language with texts, S.A.Alennikova's formation of elementary school children's communicative speaking skills through text, A.V. Shubayeva's development of elementary school children's connected speaking skills through text, A.Zhumabayeva's development of language during elementary school, A.Zhapbarov's development of learner's speech culture through constructing text, R.Shakhanov's teaching Kazakh language to Russian audience with text.

According to these opinions, text is the full version of essay made of sentences or, at least, its important part. Our object of research is scientific and pedagogical basis of formation individual's, M.A. student's speech competence. If, until this time, text was created, now it will be gotten from ready texts.

In studying text structure, the main grammatical indicators are interconnectedness, purposefulness, integration, completeness and other signs with contextual and significant features. All linguistic signs are organized so to give certain information. It's implemented by story, reasoning, description. By acknowledging text, addressee tries to decode its conclusive information.

Now as for categories, cohesion category is provided by forms of communication that are distinguished by cohesion means with separate announcements and order: auxiliary words, pronouns, adverbs.

Continuum category is tightly connected with certain type of text and dependent on space and time.

Membership category is function of general structural plan. Its description stands near other reasons and directly connected to pragmatic setting.

Retrospection and prospection category means forms of the previous or following information.

Modal category is category that is inherent to speaking, which means foundation of communicational progress.

Integration category is the text itself. It provides course-sequence connection between text's parts and combines them not vertically but horizontally.

Completed category means finished thought. It's related to title. Title is a shortened semantic-conceptual information and develops during the process of writing the text and integrated by the end of it. If we can contemplate all these categories during the text study, further we take into consideration lingua-didactic significance.

\section{Concluding Remarks}

Cultural and linguistic competence can be represented as a system, which includes the following components: 1) the possession of basic concepts and techniques of cultural linguistics; 2) the possession of sufficient a set of culturally significant linguistic units, the ability to identify them context; 3) ability to identify particular national mentality, cultural attitudes, stereotypes, standards, presentation relying on lexical and grammatical meaning, and the importance of language units; 4) the ability to explain the productivity /unproductive, regularity / irregularity of linguistic phenomena based on characteristics of the national culture; 5) readiness intercultural communication, respect their own and others' culture;

Until this time, in system of pedagogical education the issue of formation M.A. student's competence have been addressed. Also in scientific research analysis of Paul Hager and David Beckett (Hager and Beckett, 1995), David Carr and Don Skinner (Carr and Scinner, 2009), Claire Kramsch (Kramsch, 2006), Christine Litster and Gillian Roberts (Lister 
and Roberts, 2011), Kathleen A. Brown-Rice and Susan Fours (Brown-Rice and Fours, 2013), Janet Looney (Looney, 2011) have mentions of development of future specialists' competence, but they are not systematized.

Competence comprehends such concepts as human's actions and his individual borders, motivations and objectiveness. Formation of competence means to develop individual's creative skills and reaching thinking axiom, as well as getting results. During the analysis of text's linguistics, its lingua-didactic importance is also taken into consideration. On the basis of categories mentioned above, text structure became an important problem in structuralsemantic complex of text limits. It helps learners to see text's structural-semantic side and distinguish speech competence.

In experimental part for learners' lingua-cultural aspect's basis we get the following results:

Practical competence in Kazakh speaking and writing speeches;

Theoretical competence in literature and linguistics;

Determine bearing images in nation cognition;

Meaning of connotative word, its semantics and cultural lacunae in text;

\section{References}

Arkin A. (2001). Why students do not like the lessons of the native literature.

Baydenko V.P. (2004). The Bologna process: the cellular structure of higher education reform in Europe. Moscow.

Brown-Rice K.A. \& Furr S. (2013). Preservice Counselors' Knowledge of Classmates' Problems of Professional Competency. Journalof Counseling \& Development, 91 (2): 224-233.

Carr D. \& Scinner D. (2009). The Cultural Roots of Professional Wisdom: Towards a broader view of teacher expertise. Educational Philosophy and Theory, 41 (2). 141-154.

Hager P. \& Beckett D. (1995). Philosophical underpinnings of the integrated conception of competence. Educational Philosophy and Theory, 27 (1): 1-24.

Kramsch C. (2006). From Communicative Competence to Symbolic Competence. The Modern Language Journal, 90 (2): 249-252.

Lerner I.J. (1981). Didactic principles of teaching methods. Moscow: Pedagogy, p. 186.

Litster K. \& Roberts J. (2011). The self-concepts and perceived competencies of gifted and non-gifted students: a meta-analysis. Journal of Research in Special Educational Needs, 11 (2): 130-140.

Looney J. (2011). Developing High-Quality Teachers: teacher evaluation for improvement. European Journal of Education, 46 (4): 440445.

Orazbayeva F.S. (2000). Language relations: theory and methods. Almaty:

Syleymenova E.D. (1989). The concept of meaning in modern linguistics. Almaty.

Ualiev N. (1984). Speech culture. Almaty: Mektep.

Zhapbarov, A. (1991). Teaching basis of Kazakh language stylistics. Almaty: Kazakh University, p.156

Zanina L.V. (2008). Competence approach to the consideration of the teacher pedagogical college. Rostov: Phoenix, pp. 110. kültürel ve dilsel yetkinlik oluşumu 